\title{
INTERFERENSI BAHASA INDONESIA DALAM PEMILIHAN KATA KERJA PADA SAKUBUN MAHASISWA SEMESTER II JURUSAN PENDIDIKAN BAHASA JEPANG TAHUN AJARAN 2016/2017 UNDIKSHA
}

\author{
I. K. Juliastika ${ }^{1}$, D.M.S. Mardani ${ }^{1}$, G.S.Hermawan ${ }^{2}$ \\ Program Studi Pendidikan Bahasa Jepang \\ UniversitasPendidikanGanesha \\ Singaraja \\ e-mail: juliastikakomang@gmail.com \\ desak.mardani@undiksha.ac.id satyahermawan@undiksha.ac.id
}

\begin{abstract}
Abstrak
Penelitian ini bertujuan untuk mengetahui pengaruh bahasa Indonesia terhadap sakubun yang dibuat oleh mahasiswa semester II Jurusan Pendidikan Bahasa Jepang UNDIKSHA. Penelitian ini mengkhususkan pada pengaruh bahasa Indonesia pada pemilihan verba bahasa Jepang. Jenis penelitian ini adalah penelitian kualitatif dengan data yang dikumpulkan dan dianalisis menggunakan metode deskriptif kualitatif. Terdapat 17 kesalahan penggunaan kata kerja bahasa Jepang yang disebabkan oleh interferensi bahasa Indoneia dari 32 sakubun yang terkumpul. Hasil penelitian menunjukan bahwa interferensi bahasa Indonesia terjadi akibat dari kurang pahamnya mahasiswa tentang penggunaan kata kerja yang tepat sesuai degan konteks kalimat. Satu kata kerja dalam bahasa Indonesia bisa memiliki banyak padanan kata dalam bahasa Jepang. Selain itu, penggunaan dari masing-masing kata perlu memperhatikan banyak aspek, seperti siapa yang bertindak sebagai pembicara, siapa yang menjadi lawan bicara dan bagaimana kedudukan masing-masing pembicara. Seperti yang ditemukan, kata "memberi" jika dicarikan padanannya dalam bahasa Jepang maka akan memunculkan banyak kata seperti 「あげます」agemasu, 「くれます」kuremasu, 「くださいます」 kudasaimasu, 「やります」yarimasu.
\end{abstract}

Kata Kunci: interferensi, sakubun, kata kerja

ガネシャ教育大学の日本語教育学科の一年生の作文において母語の影響

$$
\text { イ・コマン・ジュリアスティカ }
$$

要旨

研究の目的は日本語教育学科の一年生の作文（動詞）においてイン ドネシア語の影響を明からにすることである。研究は動詞の選択にインド ネシア語影響を特定した。データは定性記述に分析された。研究は 17 つ の使い方が間違って、理由は 32 つ集まった作文からインドネシア語影響 である。結果は以下の通りである。大学生はコンテクスに正確で動詞を使 うのがあまり理解しないので、動詞の誤った選択が発生した。インドネシ ア語の 1 つの動詞には多くの日本語の単語が含まれる可能性がある。さら に、各単語の使用では、話者としての役割、反対者、話者の位置など、多 くの側面に注意する必要である。見つかったように、日本語の同等物が見 つかった場合、「与える」という単語は、「あげます」「くれます」「く ださいいます」「やります」などの多くの単語を表示する。 キーワード：影響、作文，動詞 


\section{Pendahuluan}

Dalam mempelajari suatu bahasa, diperlukan pemahaman tentang aturan atau kaidahkaidah yang terdapat dalam bahasa tersebut. Hal ini dilakukan untuk menghasilkan bahasa yang komunikatif. Ketika menyampaikan ide, hasrat, pikiran, dan keinginan kepada seseorang, baik secara lisan muapun tulisan, orang tersebut bisa menangkap apa yang kita maksud. Jadi, fungsi suatu bahasa merupakan media untuk menyampaikan suatu makna kepada seseorang baik secara lisan maupun secara tertulis (Sutedi, 2003:2).

Dari aspek pembelajaran, bahasa memiliki kompetensi keterampilan. Kompetensi keterampilan berbahasa mencakup empat aspek, yaitu keterampilan menyimak, keterampilan berbicara, keterampilan membaca, dan Dari keempat kompetensi tersebut salah satu aspek yang perlu mendapat perhatian lebih adalah aspek menulis. Menulis merupakan suatu kegiatan menciptakan suatu catatan atau informasi pada suatu media dengan aksara. Menulis biasanya dilakukan pada kertas dengan menggunakan alat tulis seperti pena atau pensil (Achmad \& Alex, 2016:62).

Kegiatan menulis yang sampai saat ini masih dipelajari salah satunya adalah kegiatan mengarang. Mengarang adalah segenap rangkaian kegiatan seseorang dalam mengungkapkan gagasan dan menyampaikannya melalui bahasa tulis kepada masyarakat untuk dipahami (Gie, 2002:3). Penulis harus memiliki bayangan akan apa yang ditulisnya. Begitu pula bagaimana dengan cara terbaik untuk menyampaikan gagasan tersebut, apakah menggunakan paragraf berbentuk eksposisi, narasi, argumentasi, atau deskripsi. Setiap jenis karangan memiliki tujuannya sendiri. Jika penulis tidak cermat dalam memilih bentuk karangan yang akan digunakan, maka pesan yang ingin disampaikan penulis bisa tidak tercapai (Achmad \& Alex, 2016:108).

Seperti contoh pada penelitian dari Riski (2015) data pada penelitian tersebut adalah potongan kalimat pada 21 karangan mahasiswa semester VI yang dianggap tidak koherensif. Berdasarkan hasil analisis data yang telah dilakukan pada 21 karangan mahasiswa yang mengikuti mata kuliah sakubun, diperoleh data berupa kesalahan kohesi sebanyak 277 data kesalahan dimana kesalahan kohesi gramatikal sebanyak 155 data kesalahan yang terdiri atas kesalahan penunjukan, pelepasan, dan perangkaian, kohesi leksikal sebanyak 18 data kesalahan yang terdiri atas kesalahan repetisi, sinonim, hiponim, dan kolokasi, serta kesalahan lain sebanyak 144 data kesalahan. Adapun faktor penyebab kesalahan kohesi adalah interferensi antara bahasa Jepang dengan bahasa Indonesia sebagai bahasa ibu mahasiswa, banyaknya kata yang memiliki arti sama dalam bahasa Jepang, pengetahuan tentang kosa kata bahasa Jepang sedikit, mahasiswa belum mengerti konteks penggunaan partikel tertentu, mahasiswa jarang menggunakan berbagai perubahan kata kerja bahasa Jepang, mahasiswa belum berpikir dari sudut pandang pembaca orang Jepang asli dalam menulis karangan, dan mahasiswa kurang teliti dalam penulisan beberapa kata pada karangannya.

Dari contoh penelitian diatas, dalam pembelajaran sakubun ditingkat awal tersebut kita sering menemukan kejanggalan-kejanggalan dalam karangan mahasiswa. Kurang telitinya dalam menulis karangan menyebabkan penyampain maksud dari sakubun tersebut tidak bisa tersampaikan dengan baik dan benar kepada pembaca. Selain itu, pemahaman tentang seluk-beluk mengenai kata kerja bahasa Jepang belum dipahami dengan baik oleh mahasiswa sehingga kata kerja di dalam kalimat mengalami kesalahan.

Mahasiswa sering mengalami ketimpangan dalam pemilihan kata kerja dalam sakubun dikarenakan dalam bahasa Jepang banyak verba yang berbeda tetapi memiliki arti yang sama dalam bahasa Indonesia sebagai contoh ketika mahasiswa ingin mengungkapkan "mencucui pakaian" dalam hal ini mahasiswa keliru dalam memilih dan menggunakan kata kerja yang tepat. Dalam KBBI penggunakan kata kerja seperti mencuci bisa dipergunakan untuk melengkapi kalimat seperti mencuci pakaian, mencuci tangan, dan yang lainnya namun dalam bahasa Jepang ada beberapa verba yang berbeda dan memiliki arti yang sama yang tidak bisa dipergunakan untuk melengkapi kalimat yang sudah memiliki kata 
kerjanya sendiri. menggunakan kata kerja arau dalam melengkapi kalimat "mencuci pakaian" merupakan pemilihan kata kerja yang salah.

Dari contoh singkat di atas, terlihat mahasiswa masih dipengaruhi oleh bahasa Indonesia dalam pembuatan sakubun. Kesalahan mahasiswa lebih cenderung ke dalam pemilihan kata kerja. Pemahaman kalimat yang masih kurang, dan kuatnya pengaruh dari bahasa yang dipergunakan sehari-hari yaitu bahasa Indonesia sering kali membuat karangan yang dibuat oleh mahasiswa tidak tersampaikan dengan baik kepada pembaca. Penulis berkeinginan untuk menganalisis kesalahan sakubun yang masih dipengaruhi oleh bahasa Indonesia mahasiswa semester II Jurusan Pendidikan Bahasa Jepang tahun pelajaran 2016/2017 UNDIKSHA.

Berdasarkan latar belakang yang telah dipaparkan, maka dapat dirumuskan permasalahan adalah sebagai berikut: Bagaimanakah bahasa Indonesia mempengaruhi pemilihan kata kerja (doushi) pada sakubun mahasiswa semester II Jurusan Pendidikan Bahasa Jepang tahun 2016/2017?

\section{Kajian Pustaka}

\section{Teori Semantik}

Penelitian ini menggunakan teori semantik. Semanik adalah bagian dari tatabahasa yang meneliti makna dalam bahasa tertentu, mencari asal mula dan perkembangan arti suku kata (Slamet, 2014:21). Dengan kata lain,semantik adalah salah satu cabang ilmu bahasa yang menyelidiki seluk beluk makna suatu kata dan perkembangan maknanya secara berkesinambungan.

Demikian halnya dengan Sutedi (2003:103) semantik (imiron) merupakan salah satu cabang linguistik (gengokaku) yang membahas tentang makna. Semantik memegang peranan penting, karena bahasa yang digunakan dalam komunikasi tiada lain hanya untuk menyampaikan suatu makna. Misalnya, seseorang menyampaikan ide dan pikiran kepada lawan bicara, lalu lawan bicara bisa memahami apa yang dimaskud, karena ia bisa menyerap makna yang disampaikannya.

Objek kajian semantik antara lain makna kata (go no imi), relasi makna (go no imi kankel), antar suku kata dengan yang lainya, makna frase dalam suatu idiom (ku no imı), dan makna kalimat (bun no imi) (Sutedi, 2003:103). Berikut adalah mengapa hal-hal tersebut dijadikan objek kajian semantik.

\section{a. Makana kata satu persatu}

Makna setiap kata merupakan salah satu objek kajian semantik, karena komunikasi menggunakan suatu bahasa yang sama seperti bahasa Jepang, baru akan berjalan dengan lancar jika setip kata yag digunakan oleh pembicara dalam komunikasi tersebut makna atau maksudnya sama dengan yang digunakan oleh lawan bicara (Sutedi, 2003:103)

Dalam bahasa Jepang bayak sinonim (ruigigo) dan sangat sulit untuk bisa dipadankan ke dalam bahasa Indonesia satu persatu. Ditambah minimnya buku-buku atau kamus yang bertuliskan bahasa Indonesia yang membahas secara rinci dan jelas tentang persamaan dan perbedaan dari setiap sinonim tersebut.

Selain sinonim ada juga tentang kata yang memiliki makna lebih dari satu, yaitu polisemi (tagigo). Satu kata yang berpolisemi dalam bahasa Jepang, jika dipadankan ke dalam bahasa Indonesia, bisa menjadi beberapa kata yang berbeda.

\section{b. Hubungan antar makna kata dengan dengan kata yang lainnya}

Relasi makna adalah hubungan kebermaknaan atar sebuah kata atau satuan bahasa lainya dengan kata atau atau satuan bahasa lainnya. Hubungan kebermaknaan menyangkut hal kesamaan makna, kebalikan makna, kegandaan makna, ketercakupan makna dan lain sebagainya.

Sutedi, (2003:104) relasi makna dapat dijadikan untuk menyusun kompok kata (goi) berdasarkan kategori tertentu. Misalnya, pada verba berbicara (hanasu), berkata (iu), ngomong (shaberu) dapat dikelompokan ke dalam kotoba wo hassuru (bertutur). Contoh 
lainya, hubungan makna antar kata.misalkan berbicara (hanasu) dan berkata (iu), tinggi (takal) dan rendah (hikui), binatang (doubutsu) dan anjing (inu) akan berlainan dan perlu diperjelas. Pasangan pertama merupakan sinonim, pasangan kedua merupakan antonim dan pasangan ketiga merupakan hubungan superordinat.

\section{Kesalahan Berbahasa}

Kesalahan berbahasa merupakan sisi yang mempunyai cacat pada ujaran atau tulisan sang pelajar. Kesalahan tersebut merupakan bagian-bagian konversasi atau komposisi yang menyimpang dari norma baku atau norma terpilih dari performansi bahasa orang dewasa. Para guru dan orang tua terlebih para ibu yang telah berupaya memenangkan pertarungan begitu lama dan sabar terhadap kesalahan berbahasa murid-murid dan anak-anak mereka tiba pada satu kesimpulan, pada suatu realisasi, bahwa berbuat kesalahan merupakan suatu bagian belajar yang tidak terhindarkan.

Bahasa Jepang sebagai bahasa asing tentu memiliki banyak perbedaan dengan bahasa ibu pembelajar. Perbedaan tersebut diantaranya melitputi kosakata, bunyi, intonasi, struktur kalimat, tata bahasa. Diantara perbedaan tersebut Sutedi (2011:46-47) menyebutkan berbagai kendala yang muncul ketika belajar tata bahasa Jepang antara lain:

1. Ketidakjelasan tentang perbedaan makna dan fungsi dari kata yang bersinonim menjadi penyebab munculnya kesalahan berbahassa.

2. Pembelajar ketika ingin mengetahui makna kata, ia selalu tergantung pada kamus yang tidak ada penjelasannya secara lengkap.

3. Perbedaan jenis kata yang merujuk pada makna yang sama dalam bahasa ibu, bisa menyebabkan terjadinya kesalahan berbahasa.

4. Pada pembelajar tingkat dasar, biasanya budaya (kebiasaan) dalam bahasa lbunya sering mempengaruhi dalam penggunaan bahasa Jepang (interferensi), yaitu dengan cara memasukan kaidah bahasa Indonesia ke dalam bahasa Jepang.

\section{Analisis Kesalahan}

Dalam shinpan kyouiku jiten (2005: 169) analisis kesalahan diartikan sebagai berikut:

誤用研究学習者がおこす誤りについて、どのような誤用が存在するのか、どうして誤り をおこすのうか、どのように訂正すればよいかなどを考え、日本語教育,日本語学習などに役 立つとする原因である。

Penelitian kesalahan adalah penelitian mengenai kesalahan yang dilakukan pembelajar seperti; bagaimana tingkat kesalahannya, mengapa menimbulkan kesalahan, dan bagai mana perbaikannnya sehingga bermanfaat bagi pembelajaran bahasa Jepang maupun pelajaran bahasa Jepang ${ }^{1}$.

Analisis kesalahan adalah suatu prosedur kerja yang biasa digunakan oleh peneliti ataupun guru bahasa, yang meliputi kegiatan mengumpulkan sampel kesalahan, mengidentifikasi kesalahan yang terdapat dalam sampel, dan mengevaluasi taraf keseriusan kesalahan tersebut (Tarigan dan Sulistyaningsih, 1996:25). Analisis kesalahan ini muncul sebagai upaya untuk menerangkan kesalahan yang dilakukan pembelajar dan tidak dapat dijelaskan oleh analisis kontrastif (Muhamad Geo, 2018)

\section{Pengaruh Bahasa Ibu Terhadap Bahasa Sasaran}

Bahasa ibu sebagai bahasa pertama yang diperoleh setiap individu, memiliki peran besar terhadap perkembangan bahasa selanjutnya (Irwansyah, 2017). Selain itu, Bahasa pertama atau bahasa yang diperoleh sebelumnya, berpengaruh terhadap proses penguasaan bahasa kedua dari peserta didik (Ellis, 2004), bahkan bahasa pertama telah lama dianggap sebagai pengganggu peserta didik dalam menguasai bahasa kedua.

Jika stuktur bahasa pertama sama atau mirip dengan bahasa kedua, pembelajaran akan lebih mudah mentransfernya. Jika perbedaan antar keduanya tidak disadari oleh pembelajar, kemungkinan terjadi transfer negatif, yang pada akhirnya memunculkan peristiwa interferensi

\footnotetext{
${ }^{1}$ Ivond Mangerongkonda. "analisis kesalahan penggunaan kata kerja kausatif", dalam http://lib.unnes.ac.id/18557/1/2302408063.pdf.
} 
(sengaja menggunakan kaidah bahasa pertama untuk bahasa kedua), kesilapan (kesalahan yang dibuat secara insidental karena tidak sengaja), dan kesalahan (yaitu kesalahan yang muncul secara konsisten karena ketidak tahuan). Dengan demikian, dapat diketahui bahwa bahasa pertama berpengaruh terhadap proses penguasaan bahasa kedua ${ }^{2}$.

\section{Doushi (Verba)}

Doushi (verba) adalah salah satu kelas kata dalam bahasa Jepang, sama dengan ajektiva-i dan ajektiva-na menjadi salah satu jenis yougen, kelas kata ini dipakai untuk menyatakan aktivitas atau keberadaan sesuatu (Sudjianto dan Ahmad Dahidi, 2014:149). Doushi dapat mengalami perubahan dan dengan sendirinya dapat menjadi predikat (Sudjianto dan Ahmad Dahidi, 2014:149). Sebagai contoh, perhatikan kalimat berikut.

1. Amirusan wa nihon e iku. 'Amir (akan) pergi ke Jepang'

2. Tsukue no ue ni rajio ga aru. 'Diatas meja ada radio'

3. Indonesia wa shigen ni tondeiru. 'Indonesia kaya akan sumber alam'

Kata iku, aru, dan tomu pada kalimat-kalimat di atas termasuk doushi. Kata iku pada kalimat satu menyatakan aktivitas Amir yang akan pergi ke Jepang, kata aru pada kalimat kedua menyatakan keberadaan (eksistensi) radio di atas meja, sedangkan kata tomu pada kalimat ketiga menyatakan keadaan Negara Indonesia yang kaya akan sumber alam. Katakata seperti itu dapat mengalami perubahan tergantung pada konteks kalimatnya. Doushi termasuk jiritsugo, dapat membentuk sebuah bunsetsu walau tanpa bantun kelas kata lain, dan dapat menjadi predikat bahkan dengan sendirinya memiliki kompetensi utuk menjadi sebuah kalimat (Sudjianto dan Ahmad Dahidi, 2014:149). Selain itu verba juga dapat menjadi keterangan bagi kelas kata lainya pada sebuah kalimat, dalam bentuk kamus selalu diakhiri dengan vocal/u/, dan memiliki bentuk perintah (Sudjianto dan Ahmad Dahidi, 2014:149).

a. Jenis-Jenis Doushi

1) Jidoushi

2) Tadoushi

3) Shodoushi

\section{Perubahan Bentuk Verba}

Verba bahasa Jepang dalam bentuk kamus (jishokei) berdasarkan pada perubahannya digolongkan dalam tiga kelompok berikut Sutedi (2003).

a. Kelompok I

Kelompok ini disebut dengan 五段動詞 (godan-doushi), karena mengalami perubahan dalam lima deretan bunyi bahasa Jepang, yaitu あ、い、う、え、お $(a, i, u, e, o)$. Cirinya yaitu verba yang berakhiran (gobi) huruf う、つ、る、く、ぐ、む、ぬ、ぶ、す(u-tsu-ruku-gu-mu-nu-bu-su).

b. Kelompok II

Kelompok ini disebut dengan 一段動詞 (ichidan-doushi), karena perubahanya terjadi pada suatu deretan bunyi saja. Ciri utama dari verba ini, yaitu berakhiran suara える $(e-r u)$ yang disebut kami-ichidan-doushi dan berakhiran いる (i-ru) yang disebut shimo-ichidan-doushi.

c. Kelompok III

Verba kelompok III merupakan verba yang perubahannya tidak beraturan, sehingga disebut 変格動詞 (henkaku-doushi) dan hanya terdiri dari dua verba.

Perubahan bentuk kata (yaitu: verba, ajektiva, dan kopula) disebut 勝用 (konjugasi) konjugasi verba bahasa Jepang secara garis besarnya ada enam macam seperti berikut.

a. 視線形 (mizenkel), yaitu perubahan bentuk verba yang di dalamnya menyangkut bentuk menyangkal (bentuk nai), bentuk maksud (bentuk ou/you), bentuk pasif (reru) dan bentuk menyuruh (bentuk seru).

\footnotetext{
${ }^{2}$ Fitri, Aulia. "PENGARUH BAHASA IBU TERHADAP PENGUASAAN BAHASA ASING",
} 
b. 連用形 (renyoukeI), yaitu perubahan bentuk verba yang mencakup bentuk sopan (bentuk masu), bentuk sambung (bentuk te), dan bentuk lampau (bentuk ta).

c. 終止形 (shuushikel), yaitu verba bentuk kamus yang digunakan di akhir kalimat.

d. 連体形 (rentaikeI), yaitu verba bentuk kamus yang digunakan sebagai modifikator.

e. 仮定形 (kateikel), yaitu perubahan verba ke dalam bentuk pengandaian (bentuk ba).

f. 命令形 (meireikel), yaitu perubahan verba ke dalam bentuk perintah.

Dari jenis perubahan di atas, shuushikei dan rentaikei kedua-duanya merupakan perubahan bentuk kamus, yaitu bentuk yang tercantum dalam kamus. Perbedaannya, shuushikei digunakan di akhir kalimat atau sebagai predikat. Sedangkan rentaikei berfungsi untuk menerangkan nomina yang mengikutinya. Berikut ini adalah perubahan bentuk verba bentuk renyoukei.

\section{Kalimat Bahasa Jepang}

Menurut Sudjianto dan Ahmad Dahidi (2014:182) bahwa kalimat bahasa Jepang dapat terbentuk dari sebuah bunsetsu, dua buah bunsetsu, atau terdiri dari sejumalah bunsetsu. Kalaupun sebuah kalimat terdiri dari beberapa bunsetsu, namun kalimat tersebut tidak dibentuk secara sembarangan, melainkan harus tersusun rapi berdasarkan sruktur yang benar sesuai dengan aturan gramatikanya. Hirai Masao (dalam Sudjianto dan Ahmad Dahidi, 2014:182) menyebutkan enam macam hubungan antar sebuah bunsetsu dan bunsetsu lainya pada sebuah kalimat. Hubungan tersebut adalah sebagai berikut.

1. Hubungan 'Subjek-Predikat' (Shugo-Jutsugo no KankeI)

2. Hubungan 'Yang Menerangkan-Yang Diterangkan' (Shuushoku-Hishuushoku no kankel)

3. Hubungan setara (Taitou no kankeı)

4. Hubungan tambahan (Fuzoku no Kankel)

5. Hubungan konjungtif (Setsuzoku no KankeI)

6. Hubungan bebas (Dokuritsu no kankei)

\section{Metode}

\section{Pendekatan dan Jenis Penelitian}

Pendekatan dalam penelitian ini menggunakan pendekatan kualitatif. Jenis penelitian ini merupakan penelitian deskriptif kualitatif.

\section{Lokasi Penelitian}

Dalam penelitian ini penulis melakukan penelitian di Univesitas Pendidikan Ganesha tepatnya di Jurusan Pendidikan Bahasa Jepang.

\section{Sumber Data}

Dalam penelitian ini sumber data yang digunakan adalah sakubun yang dibuat mahasiswa semester II jurusan Pendidikan Bahasa Jepang angkatan 2016/2017. Data yang dicari peneliti berupa kata kerja yang masih teridentifikasi dipengaruhi oleh bahasa Indonesia.

\section{Metode Pengumpulan Data}

Metode pengumpulan data merupakan langkah yang paling utama dalam penelitian, karena tujuan utama dari penelitian adalah mendapatkan data (Sugiyono, 2015:308). Tanpa mengetahui metode pengumpulan data, maka peneliti tidak akan mendapatkan data yang memenuhi standar data yang ditetapkan.

Dalam pengumpulan data ini dibagi menjadi dua tahap, yaitu tahap persiapan dan tahap pelaksanaan. Pada tahap persiapan terdapat persiapan yang bersifat konseptual, teknis dan administratif. Sedangkan pada tahap pelaksanaan pengumpulan data disesuaikan dengan metode pengumpulan data yang digunakan.

\section{Instrumen Penelitian}

instrumen penelitian yang digunakan adalah kartu data. Kartu data ini digunakan untuk menganalisis pemilihan kata kerja. 
Tabel 3. 1 Kartu Analisis

\begin{tabular}{|l|l|}
\hline Kalimat dalam sakubun & Kata kerja yang salah dalam kalimat \\
\hline & \\
& \\
\hline
\end{tabular}

\section{Teknik Analisis Data}

Dalam penelitian ini, data yang berupa kata kerja akan dianalisis secara deskriptif kualitatif. Data yang diperoleh dari sakubun yang masih berupa karangan, diambil kata kerja dan kalimat yang teridentifikasi mendapatkan pengaruh dari bahasa Indonesia kemudian dimasukkan ke dalam instrumen penelitian yang sudah dirangcang sebelumnya. Setelah hal ini dibuat dan ditindak lanjuti dengan pemberian penjelasan yang sebelumnya kalimat telah diberikan penomeran secara berurut.

Kerangka tersebut digunakan sebagai acuan peneliti untuk menjabarkan tabel yang telah diuraikan sebelumnya. Dalam menganalisis, terdapat penggalan kalimat tempat kata kerja yang salah dan pengalan karangan tempat struktur kalimat yang salah kemudian diikuti dengan penulisan dengan menggunakan huruf latin, kata kerja atau kalimat yang salah diberi garis bawah dengan tujuan untuk memfokuskan perhaatian pada objek yang diteliti. Dari langkah-langkah tersebut dapat dijabarkan tahap-tahap penelitian yaitu sebagai berikut.

1) Analisis Awal

2) Analisis Lanjutan

3) Analisis Akhir

\section{Hasil dan Pembahasan}

Penulis berhasil mengumpulkan sejumlah sakubun yang telah dibuat oleh mahasiswa semester II Jurusan Pendidikan Bahasa Jepang UNDIKSHA. Mahasiswa semester II angkatan 2016/2017 terbagi ke dalam 2 kelas dengan jumlah mahasiswa kelas A adalah sebanyak 18 orang dan kelas B sebanyak 14 orang, sehingga jumlah semua mahasiswa menjadi 32 orang. Semua mahasiswa mengumpulkan sakubun sehingga jumlah sakubun yang terkumpul secara keseluruhan 32 buah sakubun yang bertemakan himana toki dengan rata-rata 400 karakter atau 1 lembar genkouyoushi pada setiap sakubun-nya.

Terdapat 17 kesalahan dalam pemilihan kata kerja pada sakubun yang dibuat oleh mahasiswa. Sakubun tersebut terindikasi dipengaruhi oleh bahasa Indonesia

\section{Data 1}

ごはんを食べてしゅくだいをかきます。

Gohan wo tabete shukudai wo kakimasu.

Maksud yang ingin disampaikan oleh subjek adalah makan sambil mengerjakan pekerjaan rumah (PR). Dalam hal ini kekeliruan yang dilakukan oleh subjek adalah menggunakan kata kerja 書きます sebagai kata kerja dari 宿題.

Dari hasil wawancara yang di lakukan terhadap subjek dapat dijelaskan bahwa interferensi bahasa Indonesia yang terjadi pada kalimat ini adalah subjek terbiasa 
menggunakan kata かきます kakimasu Seharusnya penulisan yang benar adalah ごはんを食 べてしゅくだいをします。Gohan wo tabete shukudai wo shimasu.

\section{Data 2}

どうやって料理を作るか教えられます。

Douyatte ryouri wo tsukuruka, oshieraremasu.

Sebenarnya penggunaan oshieraremasu dalam kalimat ini tidaklah salah, baik dari segi gramatikal maupun jika diterjemahkan ke dalam bahasa Indonesia. Tetapi jika dipandang dari makna yang tersirat, terdapat perbedaan pemaknaan dari ma sing-masing bahasa tersebut.

Maksud yang ingin disampaikan oleh pembuat sakubun adalah bahwa ia diajarkan bagaimana cara memasak, dalam hal ini yang mengajarkannya adalah ibunya sendiri. Kesalahan ini terkait pada kata kerja pasif dalam bahasa Jepang. Pemilihan kata kerja yang di pakai dalam melengkapi kalimat tersebut tidak keliru tetapi, terdapat perbedaan makna jika bentuk pasif dalam bahasa Indonesia diterjemahkan langsung ke dalam bahasa Jepang tanpa memperhatikan nuansa yang ada dalam kalimat tersebut.

. Karena pola kalimat ini menyatakan rasa terima kasih orang pertama atas perbuatan orang kedua, maka pola kalimat yang digunakan pada waktu orang pertama berterima kasih pada perbuatan orang kedua. Untuk itu, seharusnya dituliskan menjadi 教えてもらいます atau bisa juga dengan menggunakan 教えてくれます.

Dari hasil wawancara yang dilakukan interferensi yang terjadi pada kalimat ini karena kekeliruan subjek tentang kata kerja pasif dalam bahasa Indonesia yang secara langsung di terjemahkan ke dalam bahasa Jepang. Hal ini dipengaruhi oleh penguasaan tentang penggunaan kata kerja pasif. Berdasarkan wawancara yang telah dilakukan, subjek cenderung tidak bisa membedakan kapan kata kerja pasif digunakan dan pada situasi bagaimana kata kerja tersebut digunakan. Kalimat yang benar yang seharusnya ditulis oleh subjek adalah どうやって料理を作るか教えてもらいます。Douyatte ryouri wo tsukuruka, oshietemoraimasu.

\section{Data 3}

高校生の時から今までギターを勉強します。

Koukousei no toki kara ima made gitaa wo benkyoushimasu.

Pada kalimat tersebut yang ingin disampaikan adalah "belajar bermain gitar". Dalam hal ini subjek kurang teliti menggunakan kata kerja yang tepat sesuai dengan konteks kalimat yang dibuat. Verba narau dan benkyousuru merupakan kata yang bersinonim. Bagi pembelajar bahasa Jepang, perlu diketahui bahwa tidak semua makna kosa kata dalam bahasa Jepang dapat disamakan penggunaannya kedalam bahasa Indonesia. Begitu pula pemakaiannya dalam penyusunan kalimat bahasa Jepang. Kesalahan ini terjadi bukan semata-mata karena kekeliruan pemilihan kata kerja melainkan kurangnya modalitas pembendaharaan kosakata. Penggunaan kata 勉強します benkyoushimasu pada kalimat tersebut kurang tepat. Kata 勉強します benkyoushimasu memang berarti belajar tetapi memiliki makna belajar formal dengan buku dan berkaitan dengan ilmu pengetahuan. Seperti contoh yang terdapat dibawah ini.

国で 2 か月日本語をべんきょうしました。

/kuni de 2 ka getsu nihongo wo benkyoushimashita./

(Saya belajar bahasa jepang 2 bulan di negara saya) (みんなの日本語 I:76)

Jika pembelajaran bersifat formal dalam bahasa Jepang pilihan kata kerja untuk melengkapi kalimat yang tepat adalah 勉強します benkyoushimasu. Jadi kata yang seharusnya digunakan adalah 習います naraimasu yang berarti belajar tetapi memiliki makna belajar informal dan berkaitan dengan hal-hal yang bersifat praktis seperti belajar alat musik, tarian dan lainnya. Seperti contoh di bawah ini.

$$
\text { ピアノを小さいころから習った。 }
$$




\section{/Piano wo chiisai koro kara naratta./}

(Belajar bermain piano sejak kecil)

Dalam mengungkapkan belajar dalam bahasa Jepang, perlu diperhatikan apa yang akan dipelajari karena hal tersebut akan menentukan kata kerja apa yang akan digunakan. Dari contoh di atas dapat diketahui bahwa makna kata narau adalah kegiatan mempelajari suatu hal yang berhubungan dengan keterampilan dan dilakukan untuk menjadi mahir.Penyebab interferensi dalam kalimat ini bisa terjadi akibat subjek terbiasa menggunakan kata kerja 勉強します benkyoushimasu dalam setiap kegiatan belajar. Kalimat yang benar yang seharusnya ditulis adalah 高校生の時から今までギターを習います。Koukousei no toki kara ima made gitaa wo naraimasu.

\section{Data 4}

それから 3 時半ごろ私は母に花を売るのをてつだてくれました。

Sorekara $3 \mathrm{ji}$ han goro watashi wa haha ni hana wo uruno wo tetsudatte kuremashita.

\section{Data 5}

私はりょうしんにしあわせになりたくてくれますから、いっしょうけんめい日本語をべんき ようします。

Watashi wa ryoushin ni shiawase ni naritakute kuremasu kara, issyoukenmei nihongo wo benkyoushimasu.

Kesalahan dua kalimat di atas terkait pada kata kerja beri terima. Maksud yang ingin disampaikan dari data empat di atas adalah bahwa pada jam 3 lebih 30 menit ia memberikan bantuan kepada ibunya dengan membantu menjualkan bunga. Dalam bahasa Indonesia, untuk mengungkapkan memberi atau menerima sesuatu tidak perlu memperhatikan siapa yang memberikan atau siapa yang menerima. Semua menggunakan kata kerja yang sama, yaitu "memberi" ketika memberikan sesuatu dan "menerima" jika menerima sesuatu. Dalam bahasa Jepang, tidaklah sesederhana demikian.

Dalam mengungkapkan memberi (あげます、くれます、くださいます、やります) atau menerima (もらいます、くださいます) sesuatu perlu memperhatikan beberapa hal. Banyak aspek yang harus diperhatikan ketika menggunakan kata beri-terima, mulai dari segi siapa yang memberi dan siapa yang menerima sampai bagaimana hubungan antara yang memberi dengan yang menerima. Pada pernyataan てつだってくれました di atas, kataくれました memang memiliki makna memberi, tetapi pada konteks kalimat di atas penggunaannya salah.

Kata くれました digunakan apabila mengungkapkan seseorang telah memberikan sesuatu kepada kita selaku pembicara atau keluarga pembicara (ayah, ibu, kakak, dan yang lainya). Kata yang seharusnya digunakan adalah あげます yang juga memiliki makna kita selaku pembicara membicarakan suatu kepada orang lain. Sehingga yang seharusnya ditulis adalah てつだってあげます.

Kasus yang serupa dengan kalimat yang di atas juga ditemukan pada kalimat di data 5 . Maksud yang ingin disampaikan sebenarnya adalah bahwa ia ingin memberikan kebahagiaan kepada orang tuanya dengan cara bersungguh-sungguh belajar bahasa Jepang. Tetapi ia kurang memperhatikan siapa yang memberi dan siapa yang menerima, sehingga menggunakan kata くれます kuremasu untuk mengungkapkannya. Seharusnya kata kerja yang tepat digunakan dalam kalimat ini adalah あげます agemasu. Jadi kalimat yang tepat yang seharusnya di tulis adalah 私はりょうしんにしあわせになりたくてあげま すから、いっしょうけんめい日本語をべんきょうします。Watashi wa ryoushin ni siawase ni naritakute agemasu kara, issyoukenmei nihongo wo benkyoushimasu.

\section{Data 6}

二時半ごろおきて、もしよごれるふくがあったら、そうじします。 Ni jihan goro okite, moshi yogoreru fuku ga attara, soujishimasu. 
Pada kalimat di atas terdapat kekeliruan yang terjadi akibat subjek menggunakan kata kerja そうじします yang mengungkapkan makna membersihkan dalam konteks yg berbeda. Maksud yang ingin disampaikan subjek adalah bangun sekitar jam 2 lebih 30 menit, kemudian jika ada baju yang kotor, dibersihkan (dicuci). Tetapi pembuat sakubun memilih untuk menggunakan kata うじします yang memang memiliki arti menyapu atau membersihkan tetapi memiliki makna membersihkan ruangan 部屋をそうじします heya wo soujishimasu. Verba yang seharusnya digunakan adalah せんたくします sentakushimasu Kalimat perbaikan yang benar adalah 二時半ごろおきて、もしよごれるふくがあったら、せ んたくします。Ni jihan goro okite, moshi yogoreru fuku ga attara, sentakushimasu.

\section{Data 7}

Kasus yang serupa juga terjadi pada kalimat berikut ini.

八時から十時までふくをあらう。

Hachi ji kara juu ji made fuku wo arau.

Maksud yang ingin diungkapkan dalam kalimat ini adalah "dari jam 8 sampai jam 10 mencuci pakaian" kesalahan yang terjadi dalam kalimat ini adalah penggunaan kata kerja あ ら う arau yang artinya dapat dipadankan dengan kegiatan mencuci dalam bahasa Indonesia. Tetapi dalam bahasa Jepang penggunaan kata kerja ini kurang tepat karena kegiatan mencuci pakaian dalam bahasa Jepang sudah memiliki kata kerjanya sendiri yaitu 選択します sentakushimasu. Kurang telitinya mahasiswa dalam memilih dan menggunakan kata kerja menyebabkan kalimat yang dibuat tidak berterima dalam bahasa Jepang.

Interferensi yang terjadi pada kalimat ini cenderung pada kuatnya bahasa I yang mengakibatkan penerjemahan dalam karangan tidak sesuai dengan kaidah-kaidah bahasa II, dan mahasiswa tanpa menghiraukan sesuai atau tidaknya kaidah, ia langsung memaksakannya ke dalam bahasa II. Kalimat perbaikan yang benar adalah 八時から十時ま でふくをんたくします。Hachi ji kara juu ji made fuku wo sentakushimasu.

\section{Data 8}

9 時 20 分から 10 時半までゲームをあそびます。

9 ji 20 fun kara 10 ji han made gemu wo asobimasu.

Dalam kasus ini mahasiswa ingin mengungkapkan "bermain game", tetapi dituliskan dengan”ゲームをあそびます”. Dalam bahasa Jepang kata bermain memang dapat dipadankan dengan あそびます tetapi dalam kalimat ini kurang tepat. Makna kata あそびま す sendiri memiliki makna kata secara umum, sedangkan ゲーム sendiri memiliki kata kerja sendiri yaitu します.

Coba perhatikan kalimat di bawah ini.

トランプをします

/Toranpu wo shimasul

(Bermain kartu trup) (みんなの日本語 I:46)

Verba yang digunakan dalam melengkapi kalimat yang berisikan aktivitas olahraga atau permainan menggunakan verba します. Dalam hal ini subjek keliru dan menganggap bahwa kata “あそびます” bisa digunakan pada setiap kata bermain dalam bahasa Indonesia. Kalimat perbaikan yang benar adalah 9 時 20 分から 10 時半までゲームをします。9 ji 20 fun kara 10 ji han made gemu wo shimasu.

\section{Data 9}

8 時から 9 時半まで母とりょうりをする。それから血をせんたくします。 8 ji kara 9 ji han made haha to kyouri wo suru. Sorekara sara wo sentakushimasu.

Maksud yang ingin disampaikan oleh subjek dalam hal ini adalah "dari jam 8 sampai jam 9 bersama ibu memasak setelah itu mencuci piring" Pemilihan kata kerja せんたくします sentakushimasu dalam kalimat tersebut kurang tepat. Berdasarkan wawancara yang telah 
dilakukan, subjek mengira kata kerja sentakushimasu ini bisa dipakai untuk semua kegiatan yang berhubungan dengan mencuci dalam bahasa Indonesia hal ini keliru. Mencuci piring dalam bahasa Jepang adalah 皿をあらう sara wo arau (Matsuura, 2005:28). Arau dan sentakushimasu memang bersinonim sama seperti kata agaru dan noboru karena ada kemiripan makna dikatakan bersinonim. Kalimat perbaikan yang benar adalah 8 時から 9 時 半まで母とりょうりをする。それから血をあらう。8 ji kara 9 ji han made haha to kyouri wo suru. Sorekara sara wo arau.

\section{Data 10}

新しいシャツをつかって,それからさんぽうします。

Atarashii shatsu wo tsukatte, sorekara sanpoushimasu.

Kesalahan yang terjadi pada kalimat ini adalah ketika subjek menggunakan kata 使う tsukau dalam melengkapi kalimat yang berisi memakai pakaian シャツを使って. Menurut kamus yang ditulis oleh Kenji Matsuura, kata tsukau 使う jika diterjemahkan dalam bahasa Indonesia yaitu menggunakan, mendayagunakan. Contoh penggunaannya antara lain menggunakan otak, 頭を使う、menggunakan bahasa Inggris 英語を使う. Terjadinya kesalahan dalam pemilihan kosa kata khususnya kata kerja doushi pada kalimat di atas akibat kurang pahamnya subjek tentang kapan kosa kata tersebut digunakan, maka sering menimbulkan kesalahan berbahasa pada pembelajar pemula. Menerjemahkan secara langsung tanpa mengetahui kaidah-kaidah dalam penggunaan kata kerja yang sesuai dengan kalimat menyababkan interferensi bahasa pertama terjadi. Dalam kalimat tersebut yang seharusnya subjek pakai dalam melengkapi kalimatnya supaya menjadi kalimat dengan kata kerja yang benar adalah 着て (kite). Kalimat perbaikan yang benar adalah 新しいシャツ を着て,それからさんぽうします。Atarashii shatsu wo kite, sorekara sanpoushimasu.

\section{Data 11}

とちゅうでやめよと思たこともやりましたが私の夢に思いで、もっとがんばって、勉強をつ ずけることにしました。

Tochuu de yameyou to omotta koto mo arimashita ga watashi no yume ni omoide, motto ganbatte, benkyou wo tsuzukeru koto ni shimashita.

Maksud yang ingin disampaikan sebenarnya adalah bahwa ketika ia pernah berpikir untuk berhenti belajar bahasa Jepang, tetapi ia berpikir (teringat) akan mimpinya dan kembali bersemangat untuk melanjutkan belajar bahasa Jepang. Kesalahan yang dilakukan adalah penggunaan kata omou untuk mengungkapkan "berpikir (teringat)". terbiasa menggunakan kata omou pada

Kalimat perbaikan yang benar adalah とちゅうでやめよと思たこともやりましたが私の 夢に考えて、もっとがんばって、勉強をつずけることにしました。Tochuu de yameyou to omotta koto mo arimashita ga watashi no yume ni kangaete, motto ganbatte, benkyou wo tsuzukeru koto ni shimashita.

\section{SIMPULAN DAN SARAN}

Simpulan dari penelitian ini adalah sebagai berikut:

1. Interferensi Bahasa Indonesia mempengaruhi sakubun yang dibuat oleh mahasiswa semester II jurusan Pendidikan Bahasa Jepang UNDIKSHA khususnya dalam pemilihan kata kerja disebabkan oleh pemahaman terhadap kata kerja bahasa Jepang kurang menyeluruh. Hal ini bisa terlihat pada:

a. Kurang jelinya mahasiswa memilih kata kerja dimana satu kata kerja dalam bahasa Indonesia bisa memiliki banyak padanan dalam bahasa Jepang. Penggunaan dari masing-masing kata perlu memperhatikan banyak aspek, seperti siapa yang bertindak sebagai pembicara, siapa yang menjadi lawan bicara dan bagaimana kedudukan masing-masing pembicara. Seperti yang ditemukan, kata "memberi" jika dicarikan padanannya dalam bahasa Jepang maka akan memunculkan banyak kata seperti あげ 
ます(agemasu), くれます(kuremasu), くださいます(kudasaimasu), やります (yarimasu).

b. Objek yang sedang dibicarakan juga akan menentukan kata kerja apa yang akan digunakan. Masing-masing objek memiliki kata kerjanya sendiri, misalnya kata "belajar". Jika objek yang dipelajari bersifat teoritis maka kata yang digunakan adalah 勉強します (benkyoushimasu), namun jika objek yang dipelajari bersifat praktis bisa menggunkan kata 習います (naraimasu).

Penulis berharap dengan adanya penelitian tentang pengaruh bahasa Indonesia pada sakubun mahasiswa semester II Jurusan Pendidikan Bahasa Jepang UNDIKSA yang menitikberatkan pada kesalahan kata kerja ini, memunculkan peneliti lain yang meneliti pengaruh bahasa Indonesia pada sakubun yang menitikberatkan pada bidang yang lainnya atau dengan menggunakan metode yang berbeda dan juga dapat menggunakan refrensi dari penelitian ini jika memang dibutuhkan.

Namun penulis juga menyadari betapa pun pentingnya penelitian ini, bisa dijadikan bahan masukan pengetahuan oleh pem belajar bahasa Jepang yang memiliki keinginan untuk memperdalam pengetahuannya tentang mengarang dalam bahasa Jepang yang baik dan benar. Semoga apa yang diinginkan oleh penulis ada manfaatnya bagi pembelajar bahasa Jepang yang ingin menggunakan laporan ini.

\section{Daftar Pustaka}

Ahmad, dan Alex. 2016. Bahasa Indonesia untuk Perguruan Tinggi. Jakarta: Gelora Angkasa Pratama.

Chaer, Abdul. 2007. Linguistik Umum. Jakarta: Rineka cipta.

Chaer, A. 2009. Psikolinguistik: kajian teoretik. Jakarta: Rineka Cipta.

Ellis, Rod. 2004. Understanding Second Language Acquisition. Cambridge: C.U.P.

Geo, Muhamad. 2018. Analisis Kesalahan Berbahasa. dalam http://ejournal .upi.edu/index.php/BS_JPBSP/article/download/12153/pdf Vol. 18, No 1, 2018.

Hastuti. 2015. Pengaruh Bahasa Pertama Terhadap Bahasa Kedua, dalam ejournal.upi.edu/index.php/mimbar/article/view/1329 Vol. 2, No. 2, 2015

Irwansyah. 2017. The Effect Of Introduction Language Toward Learning Result III Grade Student SD Pejagoan District, dalam INDONESIAN JOURNAL OF ENGLISH EDUCATION Vol. 4, NO.2, 2017

Liang Gie, The. 2002. Terampil Mengarang. Yogyakarta: Andi Offset.

Matsura, Kenji. 1994. Kamus Jepang-Indonesia. Kyoto : Kyoto Sangyo University press

Moleong, Lexy J. 2004. Metode penelitian kualiatif. Bandung: Remaja Rosdakarya

Nurgyantoro, Burhan. 2001. Penilaian dalam Pengajaran Bahasa dan Sastra. Yogyakarta: BPFE

Sudjianto. 2000. Gramatika Bahasa Jepang Modern, Bekasi: KBI.

Sudjianto, dan Ahmad Dahidi. 2014. Pengantar Linguistik Bahasa Jepang. Jakarta: Kesaint Blanc. 
Sutedi, Dedi. 2003. Dasar-Dasar Linguistik Bahasa Jepang. Bandung: Humaniora Utama Press.

Tarigan, Herry Guntur. 1986. Menyimak. Bandung: IKIP Bumisiliwangi.

Tarigan, Herry Guntur dan Tarigan Djago. 1995. Pengajaran Analisis Kesalahan Berbahasa. Bandung: Angkasa. 